\title{
The toxicity of composted sediments from Mediterranean ports evaluated by several bioassays
}

\author{
Yannick Mamindy-Pajany ${ }^{\mathbf{a}, \mathbf{b}}$, Bojan Hamer ${ }^{\mathbf{c}}$, Michèle Roméo $0^{\mathbf{b}, *}$, Florence Géret ${ }^{\mathrm{d}}$, François Galgani ${ }^{\mathbf{e}}$,
} Emina Durmiši ${ }^{\mathrm{f}}$, Charlotte Hurel ${ }^{\mathrm{a}}$ and Nicolas Marmier ${ }^{\mathrm{a}}$

\author{
a University of Nice Sophia Antipolis, LRSAE, NICE, France \\ ${ }^{\mathrm{b}}$ University of Nice Sophia Antipolis, ECOMERS, NICE, France \\ ${ }^{c}$ Ruđer Bošković Institute, Center for Marine Research, ROVINJ, Croatia \\ d University Center Jean-François Champollion, GEODE, ALBI, France \\ e IFREMER Corse, BASTIA, France \\ ${ }^{f}$ University of Pula, PULA, Croatia \\ *: Corresponding author : Michèle Roméo, email address : $\underline{\text { romeo@unice.fr }}$
}

\begin{abstract}
:
This work investigates the ecotoxicological evaluation of contaminated dredged sediments from French Mediterranean navy harbour (A), commercial port (B) and two composite specimens (C) and (D) coming from the mixture of $A$ and $B$ with other port sediments. The toxicity of elutriates from these sediments is estimated using embryo-toxicity test, Microtox ${ }^{\circledR}$ solid phase test, LuminoTox, phytotoxicity tests and genotoxicity test. Bioassay responses are not clearly correlated with chemical contamination in the whole sediment and vary as a function of tested organisms. The highest contaminated samples ( $A$ and $C$ ) are almost always more toxic than the less contaminated samples ( $B$ and $D$ ). Among composite sediments, the mixture effect with other sediments is not efficient to decrease toxicity in sample $\mathrm{C}$, suggesting that other parameters influence toxicity level such as particle size or organic matter content. These parameters should be taken into consideration in order to improve the efficiency of the mixture process and produce composite sediments with low toxicity.
\end{abstract}

Keywords : Bioassays; Dredged port sediments; Phytotoxicity; Microtox® solid phase; Embryotoxicity test; Genotoxicity 


\section{Introduction}

Worldwide, the water management and nautical functions of surface waters are threatened by settling sediments. To ensure sufficient water depth, huge amounts of sediments have to be dredged. It is estimated that in France alone, 50 million cubic meters of sediments are dredged annually in the main maritime and commercial ports (Alzieu, 1999). In the Mediterranean region, harbor areas pose major concerns because of the presence of toxic chemicals and their harmful effects on the marine ecosystems. Thus, Mediterranean coastal sediments are particularly contaminated with metals (RNO, 1998; Andral et al., 2004; Lafabrie et al., 2008; Casado-Martínez et al., 2009; Schintu et al., 2009) and organic compounds such as organotins, PAHs and PCBs (Gómez-Gutiérrez et al., 2007; Mille et al., 2007; Cassi et al., 2008). A common approach for conducting a screening sediment risk assessment is to compare available chemical data on sediments with Sediment Quality Guidelines (SQGs). At the French level, SQGs are available for management of contaminated dredged sediments for several chemicals. These regulatory SQGs, named levels $\mathrm{N} 1$ and $\mathrm{N} 2$, are defined for metals (As, $\mathrm{Cd}, \mathrm{Cu}, \mathrm{Hg}, \mathrm{Ni}, \mathrm{Zn}$ ) and PCBs. Dredgedsediment dispersal is permitted offshore when metal concentrations are lower than level 2 (N2). Disposal may be prohibited when concentrations are higher than N2 (Alzieu and Quiniou, 2001). Dredged sediments considered as highly contaminated (> N1) cannot be discharged into the sea and must be treated before storage and confined on a terrestrial site where they are considered as wastes. Ecotoxicity of sediments must be then evaluated prior to elimination or beneficial use. However, no ecotoxicological tests are defined in the legislation for the assessment of the impact of sediments on terrestrial environments. (Perrodin et al., 2006) propose an ecological risk evaluation framework for dredged materials including two steps: a simplified risk assessment based on contaminant concentrations and a risk assessment based on laboratory toxicity tests such as phytotoxicity tests or bioassays using aquatic organisms (bacteria, algae). Several tests are widely used to assess toxicity of sediment such as Microtox ${ }^{\circledR}$ solid phase test (Alzieu and Quiniou, 2001; Nendza, 2002; Libralato et al., 2008), oyster larvae abnormalities (His et al., 1999; Geffard et al., 2002; Galgani et al., 2009; Mamindy-Pajany et al., 2010), algal test (Dellamatrice et al., 2006; Perrodin et al., 2006; Moreno-Garrido et al., 2007), germination seeds (Chen et al., 2002; Bedell et al., 2003; Czerniawska-Kusza et al., 2006).

In this paper, toxicity of contaminated dredged sediments was evaluated using several bioassays. The oyster (Crassostrea gigas) embryo larval development test was selected to investigate sediment elutriate toxicity since previous studies demonstrated that it is one of the most sensitive and rapid bioassay to check sediment samples considering sub-chronic effects (Geffard et al., 2002; Libralato, 2007; Quiniou et al., 2007).

Microtox ${ }^{\circledR}$ is an acute toxicity test based on inhibition of bioluminescence of the marine bacterium Vibrio fischeri. Microtox ${ }^{\circledR}$ Solid Phase Test (MSPT) was selected since it allows an evaluation of the toxicity of re-suspended sediments (Volpi Ghirardini et al., 2009); the luminescent bacteria can get in contact with toxicants adsorbed on the particles or dissolved in the water. MSPT can be considered more ecologically relevant than elutriates or pore water tests for sediment toxicity evaluation. (Libralato et al., 2008) used this test to determine the toxicity of dredged sediments from Venice lagoon after some physico-chemical treatments. Another commercialized test, the LuminoTox, uses Stabilized Aqueous Photosynthetic Systems (SAPS, algal systems) to detect the presence of sediment contaminants that are readily soluble in an aqueous elutriates (Dellamatrice et al., 2006). When SAPS are challenged with chemicals or complex samples, that can interfere with transmission of chlorophyll fluorescence linked to Photosystems I and II reaction sites, a corresponding decrease in fluorescence emission results is measured (LuminoTox, 2005). Plant toxicity assays are also particularly relevant when phytotoxic contaminants are present in sediments. The terrestrial plants commonly used in such cases are chosen as a function of 
easy growth and germination capacity, and commercial availability. Seed germination and root elongation studies are often used as phytoxicity endpoints; they have been shown to decrease significantly in metal contaminated soils and sediments (Adam and Duncan, 2002; Chen et al., 2002; Maila and Cloete, 2002; Bedell et al., 2003). Germination and root elongation of the dicotyl flax Linum usitatissimum, the monocotyl sorgho Sorghum saccharatum and the dicotyl garden cress Lepidium sativum were used in this study to detect the phytotoxicity effects of elutriates from contaminated sediments.

The genotoxicity of contaminated wastes is not part of the basic test set in the European classification of waste (Römbke and Neumann-Hensel, 2009). However, the presence of genotoxic substances in sediments or elutriates may be potentially toxic for aquatic and terrestrial ecosystems. The most widely use genotoxicity test is the umu test (so-called because of its dependence on umuC gene induction). This test was used by several authors to detect primary DNA damage and induction of repair processes caused by chemicals and complex environmental contamination. (Reifferscheid et al., 1991; Ono et al., 1992; Hamer et al., 2000; Bihari et al., 2006). In addition, the umu test is a standardized test (ISO/DIS 13829, 2000) that was proposed by (Nendza, 2002) in a test battery approach to characterize mutagenicity effects on sediment extracts.

In this study contaminated dredged sediments from Mediterranean ports were characterized for toxicity, phytotoxicity and genotoxicity using several bioassays. Sediment samples were provided in the framework of the monitoring project SEDIMARD launched in 2002 by the French public administration from the Var area in order to examine the potential issues about the management of dredged contaminated sediments in collaboration with port authorities from France and Italy (Grosdemange et al., 2008). After some composting treatments in a pilot site, four sediment samples were taken into consideration: two sediments were dredged from the Côte d'Azur area (navy harbour, sample A and commercial port, sample B), while two others (samples $C$ and $D$ ) resulted from the mixture of sediment $A, B$ and other sediments in various proportions in order to reduce their level of contamination. This aim of this study is to assess the effect of mixture process on toxicity level of sediment samples. Integration of chemical data, already reported in (Mamindy-Pajany et al., 2010), and toxicity test results was also attempted to establish the relationship between the contamination level and the ecological risk.

\section{Materials and methods}

\subsection{Physico-chemical characterization}

After dredging, several Mediterranean port sediments were actively composted for four months (Grosdemange et al., 2008). After that two composite sediments (C and D) were prepared by mixing several sediments. Sample C is composed of $20 \%$ A, $15 \%$ B and $65 \%$ of other ports (15\% Bandol, $15 \%$ Sanary, $15 \%$ Saint Mandrier, $10 \%$ Cannes, and $10 \%$ old port of Marseille). Sample D is composed of $25 \%$ B, and $75 \%$ of other ports (25\% Bandol, $25 \%$ Sanary and $25 \%$ Saint Mandrier). Data, already reported in (Mamindy-Pajany et al., 2010), for particulate organic carbon, metals, organotins and organic pollutants in composted sediments $A, B, C$ and $D$ are shown in Table 1 . Total PAHs are defined by the sum of six PAHs (Fluoranthene, Benzo(b)fluororanthene, Benzo(k)fluoranthene, Benzo(a)pyrene, Benzo(ghi)perylene and Indeno(1,2,3-cd)pyrene). The risk quotient ( $\left.\mathrm{Q}_{\mathrm{PECm}}\right)$ is also given in Table 1. For a given sediment and a specific pollutant, the risk is represented by the ratio between the raw concentration of pollutant and a Predicted Effect Concentration (PEC), taken from the French guidelines for the management of marine dredged sediment (Alzieu and Quiniou, 2001). These individual quotients can then be aggregated to represent the global risk related to the dredged material examined (Perrodin et al., 2006) : 
$Q_{P E C_{m}}=\frac{\sum_{i=1}^{n} \frac{C_{i}}{P E C_{i}}}{n}$

With $\mathrm{C}_{\mathrm{i}}$ being the concentration measured for pollutant i ( $\mathrm{As}, \mathrm{Cd}, \mathrm{Cu}, \mathrm{Ni}, \mathrm{Pb}, \mathrm{Zn}, \mathrm{PAHs}$, $\mathrm{PCBS}$ ); $P E \mathrm{C}_{i}$ is the predicted effect concentration and $\mathrm{n}$ the number of measured pollutants. Thus, the risk quotient $\left(\mathrm{Q}_{\mathrm{PEC}}\right)$ is less than 1 if contaminant levels are less than N1 level, and higher than 1 if contaminant levels exceed N1 level.

\subsection{Embryo-toxicity test}

The sub-chronic test with Crassostrea gigas is based on the observation of embryo-larval development abnormalities. The percentages of abnormalities were determined for a 1:4 sediment/water ratio at an elutriate concentration corresponding to $250 \mathrm{~g}$ dried sediments/L (Galgani et al., 2009). Reference water was collected offshore Bastia (Corsica) and filtered on $0.22 \mu \mathrm{m}$ membrane just before use. Conditioned oyster adults were purchased from the Guernsey Sea Farm Ltd. hatchery (Guernsey, UK) and the test was carried out as described by (His et al., 1999) and (Damiens et al., 2006). The mature genitors were carefully cleaned and immerged in unfiltered reference water at $18{ }^{\circ} \mathrm{C}$ for 30 min before a thermal shock (28 $\left.{ }^{\circ} \mathrm{C}, 30 \mathrm{~min}\right)$. Specimens emitting gametes were placed in 2 successive baths of filtered reference water. Fertilization was monitored under the microscope; the larvae were then placed in the Iwaki micro-plates (300 larvae/well) and placed in culture at $23 \pm 1{ }^{\circ} \mathrm{C}$ for $24 \mathrm{~h}$. After incubation, larvae were fixed in $40 \%$ formaldehyde and decanted. The abnormality rate is determined on the basis of a count of 100 larvae per well (2-5 replicates per concentration). Test result acceptability was based on controls: a) negative control as percentage of normal D-shape larvae $\geq 80 \%$ in seawater (His et al., 1999); b) positive control as Effective Concentration affecting $50 \%$ of the considered population (EC50) with respect to the reference toxicant $\left(\mathrm{Cu}\right.$ as $\left.\mathrm{Cu}\left(\mathrm{NO}_{3}\right)_{2}\right)$ falling within the acceptability range.

\subsection{Microtox ${ }^{\circledR}$ solid phase test}

The MSPT is an acute toxicity test for solid matrix based on the natural bioluminescence inhibition of marine bacterium Vibrio fischeri. The test was performed using the Azur Environmental standard protocol (Azur Environmental, 1998). Sediment samples were sieved through $2 \mathrm{~mm}$ and $10 \mathrm{~g}$ of dried sediment was re-suspended in $100 \mathrm{ml}$ of diluent solution with magnetic stirring at $1000 \mathrm{rpm}$ for $10 \mathrm{~min}$. Sub-samples from this suspension were used for serial dilutions (1.5 mL, two replicates). Dilutions were equilibrated for $10 \mathrm{~min}$ in a thermostatic bath at $15.0^{\circ} \mathrm{C}$. Afterwards, $20 \mu \mathrm{L}$ of revitalized bacteria were added to each tube, gently mixed with a pipette and left in the thermostatic bath to incubate at the same temperature for $20 \mathrm{~min}$. The bacteria were then separated from the sediment by filtration and $500 \mu \mathrm{L}$ subsample of the liquid phase was transferred into the glass cuvettes in the Microtox ${ }^{\circledR}$ analyzer and allowed to equilibrate for 5 min before reading. Light emission was recorded and the output data analyzed using Microtox ${ }^{\circledR}$ Omni software Version 1.18 (Azur Environmental, 1998). Toxic Unit at $50 \%$ of the population exhibiting a response (TU50 $=100 /$ EC50) was determined to provide values directly correlated to the toxicity magnitude. 


\subsection{Luminotox}

LuminoTox Analyzer (Lab-Bell), a special fluorometer programmed to measure photosynthetic activity based on production of chlorophyll fluorescence, can measure the corresponding photosynthetic efficiency of exposed and unexposed algal system (Chlorella vulgaris) named Stabilized Aqueous Photosynthetic System (SAPS). SAPS fluorescence emissions are measured at a wavelength $>700 \mathrm{~nm}$ after light excitation at $470 \mathrm{~nm}$. Percentages of inhibition based on exposure to different elutriates are then calculated (LuminoTox, 2005). The experimental protocol for testing sediment elutriate toxicity with LuminoTox Analyzer is performed according to (Dellamatrice et al., 2006). Elutriates were prepared using the ratio $1: 4$ (5 g dried sediments: $20 \mathrm{~mL}$ water) in $50 \mathrm{~mL}$ plastic tubes. Tubes were placed in a rotator mixer. Rotating speed was set at $20-25 \mathrm{rpm}$ at room temperature $\left(20 \pm 2{ }^{\circ} \mathrm{C}\right)$ for $4 \mathrm{~h}$. Afterwards, tubes were centrifuged $(3000 \mathrm{rpm}, 10 \mathrm{~min})$ and undiluted elutriates were tested; $100 \mu \mathrm{L}$ of SAPS are then added to $2 \mathrm{~mL}$ of elutriate. Percentages of fluorescence inhibition are measured with LuminoTox Analyzer after exposure periods of $30 \mathrm{~min}, 2 \mathrm{~h}$ and $24 \mathrm{~h}$ at room temperature $\left(20 \pm 2{ }^{\circ} \mathrm{C}\right)$. Tests were performed in the required range for temperature $\left(20 \pm 2{ }^{\circ} \mathrm{C}\right)$ and at the natural $\mathrm{pH}$ of elutriates since values are in accordance with acceptable $\mathrm{pH}$ values (6.5-7.8 \pm 0.1$)$ for SAPS.

\subsection{Phytotoxicity tests}

For phytotoxicity testing, the sediments samples were extracted with ultrapure water (1:10, dried sediment : water; $24 \mathrm{~h}$ ) according to standard method commonly applied to produce leachates for hazardous wastes (AFNOR, 1998). The choice of terrestrial plants is justified since chloride concentrations in elutriates (1:10) from composted sediments are lower than $1.5 \mathrm{~g} \mathrm{Cl}^{-} / \mathrm{L}$ (Grosdemange et al., 2008) that is an acceptable level for freshwater organisms (Postma et al., 2002). Phytotoxicity assay was first performed using seeds of Flax Linum usitatissimum. Flax seeds were obtained commercially, sorted according to size and appearance. Germination test was conducted at $25{ }^{\circ} \mathrm{C}$ over a $72 \mathrm{~h}$ test period. For each sediment sample in Petri dish $(100 \times 15 \mathrm{~mm}), 3$ sheets of filter papers were placed, then three groups of thirty seeds were added at least $0.5 \mathrm{~cm}$ from the edge, followed by wetting of filters with $5 \mathrm{~mL}$ of elutriates or ultrapure water for sediment samples and the controls, respectively. Two replicates of each sample were prepared. Covered Petri dishes were placed in humidified thermostat (HERA Cell 150, Heraeus) in the dark; percentage of seed germination inhibition was measured after $24 \mathrm{~h}$. After $48 \mathrm{~h}$, production of root biomass was determined; experiment was continued until $72 \mathrm{~h}$. Again the biomass was weighed separately for roots and seeds, and finally the sum of root elongation was measured by digital ruler. The percentage of seed germination inhibition (SG), root growth inhibition measured as biomass production (BP) and root elongation inhibition (RI) are calculated with the formula: $S G / B P / R I=(A-B) / A * 100$. Where $A$ is the mean seed germination, biomass or sum of root elongation in the controls and $B$ is the mean seed germination, biomass or root elongation in samples ( $A, B, C$ and $D)$. Total phytotoxicity index was calculated as a sum of all four measured parameters (SG, BP 48 and $72 \mathrm{~h}, \mathrm{RI}$ ).

The phytotoxkit microbiotest provided by R-Biopharm (France) was also performed since it measures decrease (or absence) of germination and growth of young roots of seeds from selected higher plants (the monocotyl sorgho Sorghum saccharatum and the dicotyl garden cress Lepidium sativum) after exposure to elutriates from contaminated sediments. Phytotoxkit makes use of flat and shallow transparent test plates composed of two compartments, the lower one containing reference soil or sediment saturated to the water holding capacity, the higher one allowing seed growth. Ten seeds were positioned at equal distance near the middle ridge of the test plate on a filter paper placed on top of the hydrated reference soil. After closing the test plates with their transparent covers, test plates were placed vertically in a holder and incubated at $25{ }^{\circ} \mathrm{C}$ for 3 days. Afterwards, number of germinated seeds is counted, the root elongation measured at the next millimeter with a 
ruler. All reported values are the average of triplicate analysis. The percentages of seed germination inhibition (SG) and root growth inhibition (RI) for each plant are calculated with the formula: $S G / R I=(A-B) / A * 100$ where $A$ is the mean seed germination or root elongation in the control hydrated with water; $B$ the mean seed germination or root elongation in the soil hydrated with contaminated elutriates.

\subsection{Umu-test}

The genotoxic effect of sediment elutriates was estimated by umu test according to standard ISO procedure (Hamer et al., 2000; ISO/DIS 13829, 2000). The umu assay originally developed by (Oda et al., 1985) is based on the use of a genetically modified Salmonella typhimurium (strain TA 1535) that contains plasmids with the fused umuC gene and the lacZ gene (pSK1002), which encode $\beta$-galactosidase. The activation of the umuC gene by DNAdamaging agents (as part of the SOS pathway) is measured by an increase of $\beta$ galactosidase activity in a colorimetric assay at $420 \mathrm{~nm}$. The test was carried out without S9 metabolic activation since metal are the main pollutants in elutriates (Mamindy-Pajany et al., 2010). Bacterial growth is measured as turbidity at $600 \mathrm{~nm}$ and growth factors are considered in the test results. Elutriates were obtained with ultrapure water (1:10 dried sediment : water; shaken $24 \mathrm{~h}$ ) and stored at $4{ }^{\circ} \mathrm{C}$ prior to genotoxicity assays. Elutriates were tested in triplicate at sediment equivalent dose $33.33 \mathrm{~g} / \mathrm{L}$. The test was performed for preliminary screening in microplate version (300 $\mu \mathrm{L})$ using $30 \mu \mathrm{L}$ and for final testing $100 \mu \mathrm{L}$ of elutriates and repeated two times. The genotoxic activities were expressed in $\beta$ galactosidase units and then as enzyme induction ratios (IR) related to control samples. Induction ratios above 1.5-fold are scored as sufficient positive results, estimated as minimal concentrations of genotoxins required to produce statistically significant increases from background controls. Bacterial growth was expressed in percent compared to the control. The results of the tests are given as mean of triplicate determination. In all experiments, the standard genotoxin 4-nitroquinoline-N-oxide (4-NQO) (Sigma, Germany) was used as positive control.

\subsection{Data analysis}

Statistical analyses were carried out using the software XLSTAT. Data were tested for homogeneity of variance and normal distribution. One way ANOVAs were used to reveal statistical differences in toxicity level. Post-hoc comparisons between control and samples were made using the Fisher's test to determine which values significantly differed.

Principal component analysis (PCA) was considered to summarize the relationships between chemical data and bioassays responses and account for the variation present in the dataset matrix via biplotting both the ordination component scores and the variable loading coefficients.

\section{Results}

\subsection{Sediment contamination}

The global risk based on pollutant concentrations (As, $\mathrm{Cd}, \mathrm{Cu}, \mathrm{Ni}, \mathrm{Pb}, \mathrm{Zn}, \mathrm{PAHs}, \mathrm{PCBs}$ ) was determined by calculating the $\mathrm{Q}_{\mathrm{PEC}}\left(\right.$ Table 1 ). Results show that $\mathrm{Q}_{\mathrm{PECm}}$ values are always higher than 1 and decrease in the following order: $A>C>B>D$. There is one order of magnitude between $Q_{P E C m}$ values from sample $A$ and others. According to $Q_{P E C m}$, mixed samples $C$ and $D$ are two-fold less polluted than $A$ and $B$, respectively. Sample $D$, coming from the mixture of sample $B$ with other port sediments, appears to be the less polluted sample with a $\mathrm{Q}_{\mathrm{PECm}}$ value equal to 1.2. 


\subsection{Embryo-toxicity test}

The Net Percentage of Abnormalities (NPA) in controls were under $12 \%$ that is acceptable for the test validity. Results from embryo-toxicity test, expressed as NPA, are shown in Fig. 1 for all sediments (A, B, C and D). The highest NPA is observed in sample $A(17.7 \pm 1.7 \%)$. Sample B presents the same toxicity with a higher variability. Samples $C$ and $D$ display lower toxicity (ca 10\%) compared to other samples. One-way ANOVA performed on these samples is significant $(p=0.006)$. Significance of post-hoc comparisons is shown in Fig. 1 . The observed toxicity in A is not significantly higher than in B. Net Percentages of Abnormalities (NPA) of these samples are significantly higher than in samples $C$ and D whereas no significant difference is found between samples $C$ and $D$.

\subsection{Microtox solid phase test (MSPT)}

Results obtained with MSPT are shown in Fig. 2. Toxicity responses expressed as TU50 range from 15 to 80 . One-way ANOVA was significant $(p=0.002)$ and the significance of post-hoc comparisons is also shown. All samples are significantly different between them. The toxicity gradient decreases in the following order: $C>A>B>D$.

\subsection{Luminotox}

No fluorescence inhibition is observed after $30 \mathrm{~min}$ in all samples and a stimulating effect on fluorescence is even observed and more particularly in A (Fig. 3). One-way ANOVA performed with the data is significant $(p<0.0001)$ and significance of post-hoc comparisons is also shown. After $2 \mathrm{~h}$, fluorescence is inhibited in B (10-15\%) and, to a lesser extent, in A. In samples $C$ and $D$, no significant change is observed. However after $24 \mathrm{~h}$, all elutriates showed chronic toxicity with a fluorescence inhibition that ranges from 10 to $20 \%$. The toxicity decreases in the following order: C > A $>B>D$.

\subsection{Phytotoxicity tests}

Phytotoxicity assay using seeds of Flax (Linum usitatissimum) shows inhibition of germination and root biomass production compared to controls; decreasing effect ranges as follows: $A>C>B>D$ (Fig. 4). One-way ANOVA performed with the data is significant $(p<$ 0.0001 ) and significance of post-hoc comparisons is also shown. After $72 \mathrm{~h}$ exposure, reduction of biomass is observed $(C>A>D>B)$, with similar results on the basis of root elongation; elutriates from samples $B$ and $D$ are less toxic than samples $C$ and $A$. Calculated total phytotoxicity index (by decreasing inhibitory effect) ranges as follows: C (144.71) A (142.83), and B (55.79) > D (53.22). The germination inhibition (GI) measured after $24 \mathrm{~h}$ represents only prolongation of germination time, because after $48 \mathrm{~h}$ the average value of all sediments samples was $>90 \%$ that is to say similar to controls.

Phytotoxicity assays using phytotoxkit show no significant difference on seed germination compared with controls and inhibition of germination cannot be determined in any sediment samples. Fig. 5 shows the inhibition of root growth for Sorghum saccharatum and Lepidium sativum after 3 days' exposure to elutriates from sediments $A, B, C$ and $D$. One-way ANOVA performed on the percentage of root inhibition is significant $(p<0.0001)$ and the significance of post-hoc comparisons is shown in Fig. 5. Compared to control, the percentage of root growth inhibition of $S$. saccharatum decreases in the following order: $C>A \sim B>D$. In $L$. sativum : root growth inhibition ranges as follows $A \sim C>B>D$ with a stimulating effect on roots from $B$ and $D$. Samples $B$ and $D$ significantly inhibit root elongation of $S$. saccharatum and, on the other hand, stimulate root growth of $L$. sativum. 


\subsection{Genotoxicity test}

In all experiments, the standard genotoxin 4-nitroquinoline-N-oxide (4-NQO) (Sigma, Germany) was used as positive control giving a mean response IR $=3.52 \pm 0.25$. The results of umu-test without metabolic activation of analyzed samples $(A, B, C, D)$ were all negative (IR < 1.5 ranging from 1.32 in $B$ and $C$ to 1.34 in $D$ and 1.37 in $A$ ), i.e. elutriates did not result in genotoxic activity/effects on tested bacteria.

\subsection{PCA analysis}

A biplot, summarizing PCA results which concern chemical and toxicity data, is shown in Fig 6. The first two principal components account for $64.61 \%$ and $23.24 \%$ of the total variance, respectively, i.e $87.85 \%$ of cumulative variance. The biplot with component loadings suggests that the first component (F1) scores are influenced by high values of $\mathrm{As}, \mathrm{Cd}, \mathrm{Cu}$, PAHs, Pb, PCBs, TBT, Zn, particulate organic carbon, which are clustered together and biological responses from LuminoTox and phytotoxicity test (Lepidium sativum). In addition, the second component scores (F2) could reflect the phytotoxicity responses (S. saccharatum and L. usitatissimum) and the acute toxicity towards Vibrio fischeri (Microtox ${ }^{\circledR}$ solid phase test).

\section{Discussion}

The ecological risk assessment framework for dredged materials includes knowledge of contaminant concentrations associated with laboratory toxicity tests (Perrodin et al., 2006). The global risk related to the sediment samples can be examined using $Q_{P E C m}$ which is the quotient predicting the toxic effect of pollutants in the whole sediments. $Q_{\mathrm{PECm}}$ values were calculated with six metal (As, $\mathrm{Cd}, \mathrm{Cu}, \mathrm{Ni}, \mathrm{Pb}, \mathrm{Zn}), \mathrm{PAH}$ and PCB concentrations in the whole sediments. Samples (A, B, C and D) have $Q_{P E C m}$ values higher than 1 , suggesting that all sediment samples can be potentially toxic for living organisms in aquatic and terrestrial environments. However, $Q_{P E C m}$ values range from 1 to 15 suggesting that the risk is very different as a function of sediment samples. The ecological risk and contamination gradient decrease in the following order : $A>C>B>D$. Sediment sample from military port $(A)$ presents the highest $Q_{P E C m}$ value, since it was collected in the military port near a ship chandler zone contaminated by copper, zinc, TBT and PAHs (Cassi et al., 2008). The composite sediment $C$ (coming from the mixture of sample $A$ and $B$ and other port sediments) has a contamination level between that of $A$ and $B$, suggesting that mixing provokes a decrease in global contamination and therefore in associated ecological risk. In the same way sample D (coming from sample B and other port sediments) has the lowest contamination degree and $Q_{P E C m}$ value. Although chemical concentrations provide useful information for the management of dredged sediment, total concentration are not always relevant to predict toxicity, bioassays are therefore necessary to assess the bioavailability of pollutants to living organisms. Ecotoxicological study was therefore performed to assess the ecological impact of these dredged sediments on several living organisms.

Embryo-toxicity test results on elutriates show that toxicity level is low since any EC 50 cannot be obtained with undiluted elutriate from 1:4 ratio. The toxicity following the order: $A \geq$ $\mathrm{B}>\mathrm{C} \geq \mathrm{D}$ does not allow to drastically discriminate samples despite different contamination levels. In another work on the same sediments (Mamindy-Pajany et al., 2010) the same toxicity rank was observed $(A>B>C>D)$, but with significant differences using sediment water ratio (1:10). In agreement with the present work, (Novelli et al., 2006) show that 1:4 sediment water ratio has not always been useful in detecting sediment toxicity, generally demonstrating a lower discriminatory capability than the ratios 1:20 and 1:50. In addition, sediment characteristics (grain size, organic carbon, contamination level) seem to play an important role in the toxicity of sediment samples. As explained in (Mamindy-Pajany et al., 
2010) dissolved organic carbon can alter the bioavailability of contaminants and grain size can increase pollutant availability but also have mechanical effect on oyster larvae (Geffard, 2001). The evaluation of sediment quality through elutriation should be preceded by a preliminary study establishing the most representative elutriation proportions to make contaminants more available toward the biota. Normalized elutriation ratios 1:4 do not seem to be the best in all cases.

The Microtox ${ }^{\circledR}$ Solid Phase Test (MSPT) provides additional information since toxicity is evaluated on dissolved and adsorbed contaminants. This test shows that the toxicity gradient decreases in the following order: $C>A>B>D$. The MSPT allows therefore discriminating the most contaminated samples $(A, C)$ with high $Q_{P E C}$ from the less contaminated ones: samples $B$ and $D$. As observed in the embryo-toxicity test, $D$ (which is composed of $B$ and other sediments) is less toxic than $B$, due to a mixture effect. This effect is not found when comparing $\mathrm{A}$ and $\mathrm{C}$ sediment toxicity. Toxicity is therefore not only depending on total contamination of sediments. (Libralato et al., 2008), working on dredged sediments from Venice lagoon, demonstrated that the finer fraction (silt and clays particles) is potentially more toxic than the coarse fraction (sand and fine sand). (Bulich et al., 1992) explained that the fine fraction can be considered as the source of toxicity due to the greater specific surface increasing bacteria exposure to toxicants. The highest toxicity found in sample $\mathrm{C}$ compared with sample A seems therefore to be associated with higher fine particle content in this sample (Table 1). Finally, toxicity results show that other factors such as particle size, organic carbon ... may be involved in the observed toxicity.

Experiment with LuminoTox showed that, after $24 \mathrm{~h}$ incubation, algal toxicity decreased in the following order: $C \geq A>B>D$. This test displays measurable toxicity responses since the most contaminated samples ( $A$ and $C$ ) inhibit more fluorescence than less contaminated ones (B and D). (Dellamatrice et al., 2006) also reported measurable fluorescence inhibition $\left(\mathrm{IC}_{20}\right)$ from contaminated sediment elutriates attributed to metals rather than organic compounds. The stimulating effect observed between 30 min and 2 hours' incubation on algal fluorescence can be explained by low bioavailable concentrations of a number of chemical in elutriates that produce hormetic effect. This was already observed by some authors on numerous organisms (Calabrese and Baldwin, 2002; Stebbing, 2002; De Nicola et al. 2007).

The phytotoxicity, studied on elutriates with three terrestrial plants (Linum usitatissimum, Sorghum saccharatum and Lepidium sativum), displayed different effects on germination and root growth (biomass, elongation). The phytotoxicity index with Linum usitatissimum ranges as follows: $C \geq A>B>D$. The most contaminated samples ( $C$ and $A$ ) are 3-fold more phytotoxic than the less contaminated ones (B and D). Phytotoxicity levels in $C$ and $A$ are similar, the same occurs for $B$ and $D$, suggesting that mixing process (with other sediments) is not efficient to decrease phytotoxicity to Linum usitatissimum. Root elongation inhibition of $S$. saccharatum decreases in the following order: $C \geq A \geq B>D$ whereas for $L$. sativum, this order is: $A \geq C>B>D$. Phytotoxicity response as inhibition of root elongation are similar in samples $C$ and $A$ for both plant species, confirming the high contamination of these samples. For the less contaminated samples (B and $D)$, phytotoxicity response is duplicate. Elutriates from these samples inhibited root elongation of $S$. saccharatum significantly and on the other hand stimulated root growth of $L$. sativum. This adverse effect was also reported by (Czerniawska-Kusza et al., 2006) for these two plant species in phytotoxicity tests performed on contaminated sediments.

Among both plant species, $S$. saccharatum appears as the most sensitive species since root elongation is inhibited for all sediment samples. This result is in agreement with work of (Czerniawska-Kusza et al., 2006) reported that S. saccharatum is the most sensitive species to identify phytotoxic sediment samples compare to L. sativum and S.alba. 
Finally, phytotoxicity tests with $L$. usitatissimum, S. saccharatum and $L$. sativum allow to discriminate two groups: the most contaminated sediments ( $A$ and $C$ ) from the least ones (B and $D$ ). However, there are no significant differences inside the groups. The wide range of root inhibition percentages indicates that the response of plant species to sediment contaminants depended not only on pollutant concentrations but also on sediment characteristics. As explained in (Czerniawska-Kusza et al., 2006), sediment organic matter content and grain size distribution can have a significant impact on plant responses.

Elutriates from all sediment samples are not genotoxic indicating that umu-test assay is not a suitable tool for determination and screening of genotoxic activities of metal contamination in sediments including water elutriates as a method of metal extraction.

Principal component analysis, integrating chemical data and toxicity responses in sediments, shows that relationships between the two kinds of variables are not clear. Samples A, B and $\mathrm{D}$ seem to follow the contamination axis (F1) and are correlated with some toxicity tests. Sample $\mathrm{C}$ is correlated with biological response axis (F2) and not with contaminants, suggesting the presence of undetermined contaminants, bioavailability and synergistic effects from this sediment sample.

\section{Conclusions}

The aim of this study was to evaluate the toxicity of port sediments (A, B, C and D), and especially composite sediments ( $C$ and $D$ ), in order to provide usefully tools for their final management. Although total concentrations of contaminants in sediments can be used for ecological risk assessment, bioassays appear to be necessary to evaluate the potential ecological impact. Toxicity results are not always clearly correlated with chemical concentrations in the whole sediments. Bioassays do not respond in the same way to sediment samples suggesting that bioavailability of contaminants can play a significant role on the observed toxicity. Samples $A$ and $C$ are more toxic to tested organisms in almost all bioassays whereas $B$ and $D$ are less toxic. In the case of composite sediments ( $C$ and $D)$, sediment $C$ appears to be in some cases more toxic than raw sediments ( $A$ and $B$ ) whereas $D$ is always less toxic than raw sediment $B$. Finally the mixing procedure experimented by port authorities to make composite sediments is not always efficient to produce less toxic sediments although chemical contamination in the whole sediment decreases. Mixing process could be improved by taking into account other parameters such as particle size and organic carbon content at the time of mixture preparation.

\section{References}

Adam, G., Duncan, H., 2002. Influence of diesel fuel on seed germination. Environmental Pollution 120, 363-370.

AFNOR, 1998. Déchets - Essai de lixiviation. XP X 31-210 AFNOR.

Alzieu, C., 1999. Dragages et environnement marin : état des connaissances. IFREMER, Nantes (France).

Alzieu, C., Quiniou, F., 2001. Géodrisk - La demarche d'analyse des risques liés à l'immersion des boues de dragage des ports maritimes, in CD-ROM Geodrisk "logiciel d'évaluation des risques liés à l'immersion des débalais de dragages des ports maritimes". 
Andral, B., Stanisiere, J.Y., Sauzade, D., Damier, E., Thebault, H., Galgani, F., Boissery, P., 2004. Monitoring chemical contamination levels in the Mediterranean based on the use of mussel caging. Marine Pollution Bulletin 49, 704-712.

Azur Environmental, 1998. Microtox Acute Toxicity Test Guide, Users Manual.

Bedell, J.-P., Briant, A., Delolme, C., Perrodin, Y., 2003. Evaluation of the phytotoxicity of contaminated sediments deposited "on soil". I. Impact of water draining from the deposit on the germination of neighbouring plants. Chemosphere 50, 393-402.

Bihari, N., Fafand ${ }^{-}$el, M., Hamer, B., Kralj-Bilen, B., 2006. PAH content, toxicity and genotoxicity of coastal marine sediments from the Rovinj area, Northern Adriatic, Croatia. Science of The Total Environment 366, 602-611.

Bulich, A.A., Greene, M.W., Underwood, S.R., 1992. Measurement of soil and sediment toxicity to bioluminescence bacteria when in direct contact for a fixed time period. Water Environmental Federation 65th Annual Conference and Exposition, New Orleans, pp. 53-63.

Calabrese, E.J., Baldwin, L.A., 2002. Applications of hormesis in toxicology, risk assessment and chemotherapeutics. Trends in Pharmacological Sciences 23, 331-337.

Casado-Martínez, M.C., Forja, J.M., DelValls, T.A., 2009. A multivariate assessment of sediment contamination in dredged materials from Spanish ports. Journal of Hazardous Materials $163,1353-1359$.

Cassi, R., Tolosa, I., Mora, S.d., 2008. A survey of antifoulants in sediments from Ports and Marinas along the French Mediterranean coast. Marine Pollution Bulletin 56, 1943-1948.

Chen, Y.X., Zhu, G.W., Tian, G.M., Zhou, G.D., Luo, Y.M., Wu, S.C., 2002. Phytotoxicity of dredged sediment from urban canal as land application. Environmental Pollution 117, 233241.

Czerniawska-Kusza, I., Ciesielczuk, T., Kusza, G., Cicho, A., 2006. Comparison of the Phytotoxkit microbiotest and chemical variables for toxicity evaluation of sediments. Environmental Toxicology 21, 367-372.

Damiens, G., Mouneyrac, C., Quiniou, F., His, E., Gnassia-Barelli, M., Roméo, M., 2006. Metal bioaccumulation and metallothionein concentrations in larvae of Crassostrea gigas. Environmental Pollution 140, 492-499.

De Nicola, E., Meriç, S., Gallo, M., Iaccarino, M., Della Rocca, C., Lofrano, G., Russo, T., Pagano, G., 2007. Vegetable and synthetic tannins induce hormesis/toxicity in sea urchin early development and in algal growth. Environmental Pollution 146, 46-54.

Dellamatrice, P.M., Monteiro, R.T.R., Blaise, C., Slabbert, J.L., Gagné, F., Alleau, S., 2006. Toxicity assessment of reference and natural freshwater sediments with the LuminoTox assay. Environmental Toxicology 21, 395-402.

Galgani, F., Senia, J., Guillou, J., Laugier, T., Munaron, D., Andral, B., Guillaume, B., Coulet, E., Boissery, P., Brun, L., Bertrandy, M., 2009. Assessment of the Environmental Quality of French Continental Mediterranean Lagoons with Oyster Embryo Bioassay. Archives of Environmental Contamination and Toxicology 57, 540-551. 
Geffard, O., 2001. Toxicité potentielle des sédiments marins et estuariens contaminés: évaluation chimique et biologique, biodisponibilité des contaminants sédimentaires, Ph.D. thesis. University of Bordeaux, France, p. 351.

Geffard, O., Budzinski, H., His, E., Seaman, M.N.L., Garrigues, P., 2002. Relationships between between contaminant levels in marine sediments and their biological effects on embryos of oyster, Crassostrea Gigas. Environmental Toxicology and Chemistry 21, 23102318.

Gómez-Gutiérrez, A., Garnacho, E., Bayona, J.M., Albaigés, J., 2007. Assessment of the Mediterranean sediments contamination by persistent organic pollutants. Environmental Pollution 148, 396-408.

Grosdemange, D., Leveque, F., Drousie, D., Aqua, J.L., Mehu, J., Bazin, C., 2008. The SEDIMARD project : presentation and results. . International Symposium on Sediment Management -I2SM, Lille (France).

Hamer, B., Bihari, N., Reifferscheid, G., Zahn, R.K., Müller, W.E.G., Batel, R., 2000. Evaluation of the SOS/umu-test post-treatment assay for the detection of genotoxic activities of pure compounds and complex environmental mixtures. Mutation Research/Genetic Toxicology and Environmental Mutagenesis 466, 161-171.

His, E., Beiras, R., Seaman, M.N.L., 1999. The assessment of marine pollution-bioassays with bivalve embryos and larvae. Advances in Marine Biology 37, 1-178.

ISO/DIS 13829, 2000. Water quality - Determination of the genotoxicity of water and waste water using the umu-test.

Lafabrie, C., Pergent-Martini, C., Pergent, G., 2008. Metal contamination of Posidonia oceanica meadows along the Corsican coastline (Mediterranean). Environmental Pollution 151, 262-268.

Libralato, G., 2007. Validation of ecotoxicological methods for wastewater monitoring to be discharged to marine-coastal and transitional environments - advanced technologies for wastewater treatment (SBR and MBR) as case studies, Ph.D. thesis. Università Cà Foscari Venezia, Venice (Italy), p. 218.

Libralato, G., Losso, C., Arizzi Novelli, A., Citron, M., Della Sala, S., Zanotto, E., Cepak, F., Volpi Ghirardini, A., 2008. Ecotoxicological evaluation of industrial port of Venice (Italy) sediment samples after a decontamination treatment. Environmental Pollution 156, 644-650.

LuminoTox, 2005. LuminoTox Analyser: Owner's Manual.Shawinigan, Quebec, Canada: Lab_Bell, Inc., p. 19.

Maila, M.P., Cloete, T.E., 2002. Germination of Lepidium sativum as a method to evaluate polycyclic aromatic hydrocarbons (PAHs) removal from contaminated soil. International Biodeterioration \& Biodegradation 50, 107-113.

Mamindy-Pajany, Y., Libralato, G., Roméo, M., Hurel, C., Losso, C., Ghirardini, A.V., Marmier, N., 2010. Ecotoxicological evaluation of Mediterranean dredged sediment ports based on elutriates with oyster embryotoxicity tests after composting process. Water Research 44, 1986-1994.

Mille, G., Asia, L., Guiliano, M., Malleret, L., Doumenq, P., 2007. Hydrocarbons in coastal sediments from the Mediterranean sea (Gulf of Fos area, France). Marine Pollution Bulletin 54, 566-575. 
Moreno-Garrido, I., Lubián, L.M., Jiménez, B., Soares, A.M.V.M., Blasco, J., 2007. Estuarine sediment toxicity tests on diatoms: Sensitivity comparison for three species. Estuarine, Coastal and Shelf Science 71, 278-286.

Nendza, M., 2002. Inventory of marine biotest methods for the evaluation of dredged material and sediments. Chemosphere 48, 865-883.

Novelli, A.A., Losso, C., Libralato, G., Tagliapietra, D., Pantani, C., Ghirardini, A.V., 2006. Is the 1:4 elutriation ratio reliable? Ecotoxicological comparison of four different sediment:water proportions. Ecotoxicology and Environmental Safety 65, 306-313.

Oda, Y., Nakamura, S.-i., Oki, I., Kato, T., Shinagawa, H., 1985. Evaluation of the new system (umu-test) for the detection of environmental mutagens and carcinogens. Mutation Research/Environmental Mutagenesis and Related Subjects 147, 219-229.

Ono, Y., Somiya, I., Kawaguchi, T., 1992. Genotoxic induction on chlorophenols using the umu test. Mutation Research/Environmental Mutagenesis and Related Subjects 272, 278279.

Perrodin, Y., Babut, M., Bedell, J.-P., Bray, M., Clement, B., Delolme, C., Devaux, A., Durrieu, C., Garric, J., Montuelle, B., 2006. Assessment of ecotoxicological risks related to depositing dredged materials from canals in northern France on soil. Environment International 32, 804-814.

Postma, J.F., de Valk, S., Dubbeldam, M., Maas, J.L., Tonkes, M., Schipper, C.A., Kater, B.J., 2002. Confounding Factors in Bioassays with Freshwater and Marine Organisms. Ecotoxicology and Environmental Safety 53, 226-237.

Quiniou, F., Damiens, G., Gnassia-Barelli, M., Geffard, A., Mouneyrac, C., Budzinski, H., Roméo, M., 2007. Marine water quality assessment using transplanted oyster larvae. Environment International 33, 27-33.

Reifferscheid, G., Heil, J., Oda, Y., Zahn, R.K., 1991. A microplate version of the SOS/umutest for rapid detection of genotoxins and genotoxic potentials of environmental samples. Mutation Research/Environmental Mutagenesis and Related Subjects 253, 215-222.

RNO, 1998. Surveillance du milieu marin. Travaux du Réseau National d'Observation. IFREMER et Ministère de l'Aménagement du Territoire et de l'Environnement, Nantes

Römbke, J., Neumann-Hensel, H., 2009. Genotoxicity Tests. Ecotoxicological Characterization of Waste. Springer New York, pp. 165-169.

Schintu, M., Marras, B., Maccioni, A., Puddu, D., Meloni, P., Contu, A., 2009. Monitoring of trace metals in coastal sediments from sites around Sardinia, Western Mediterranean. Marine Pollution Bulletin 58, 1577-1583.

Stebbing, A.R.D., 2002. Tolerance and hormesis--increased resistance to copper in hydroids linked to hormesis. Marine Environmental Research 54, 805-809.

Volpi Ghirardini, A., Girardini, M., Marchetto, D., Pantani, C., 2009. Microtox® solid phase test: Effect of diluent used in toxicity test. Ecotoxicology and Environmental Safety 72 , 851861. 


\section{Figures}

Fig.1. Mean Net Percentage of Abnormalities (NPA) of the oyster Crassostrea gigas larvae at $250 \mathrm{~g}$ sediment $L^{-1}$. Means $(n=3) \pm 1$ SD; different letters differed significantly (Fisher's test at $p<0.01)$ after significant global ANOVA $(p=0.006)$.

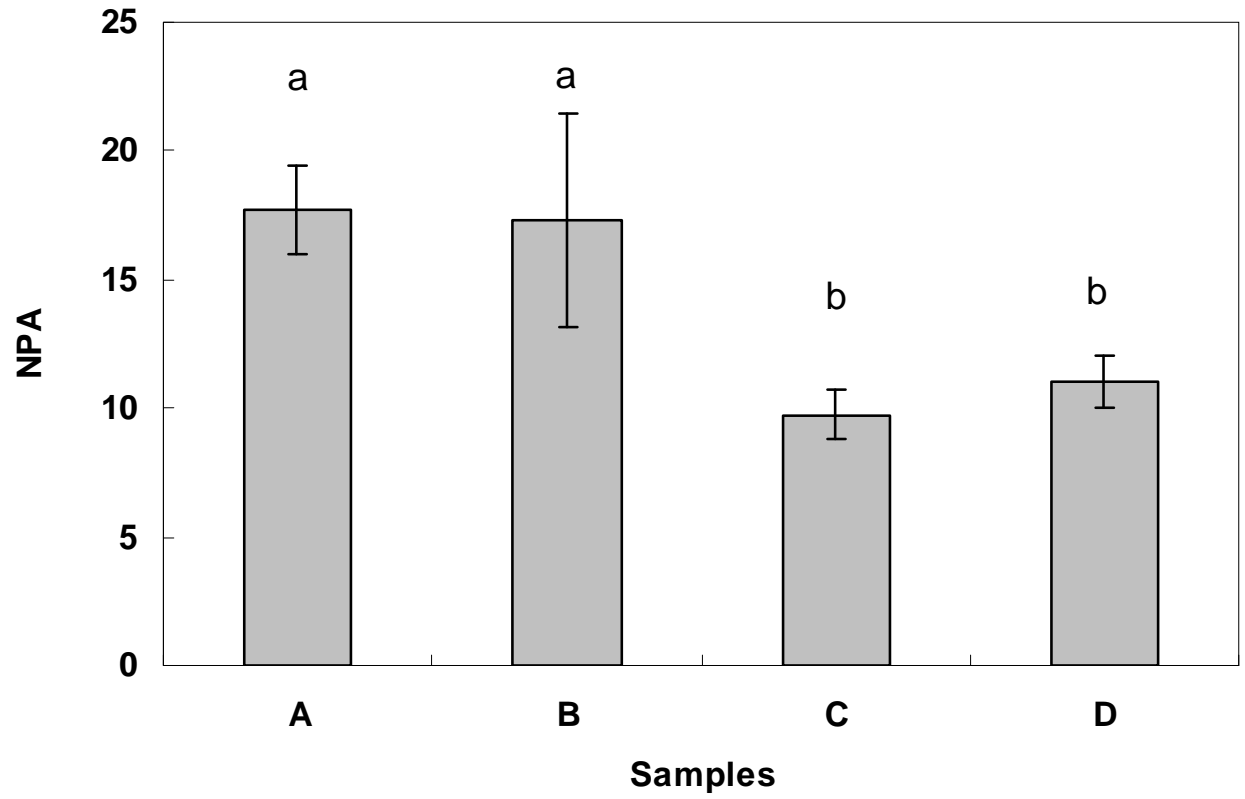

Fig.2. Microtox ${ }^{\circledR}$ solid phase test: results are presented as toxic units (TU50) that produce $50 \%$ inhibition of bioluminescence of Vibrio fischeri after 5 min. Means $(n=3) \pm 1$ SD: different letters differed significantly (Fisher's test at $p<0.005$ ) after significant global ANOVA $(p=0.002)$.

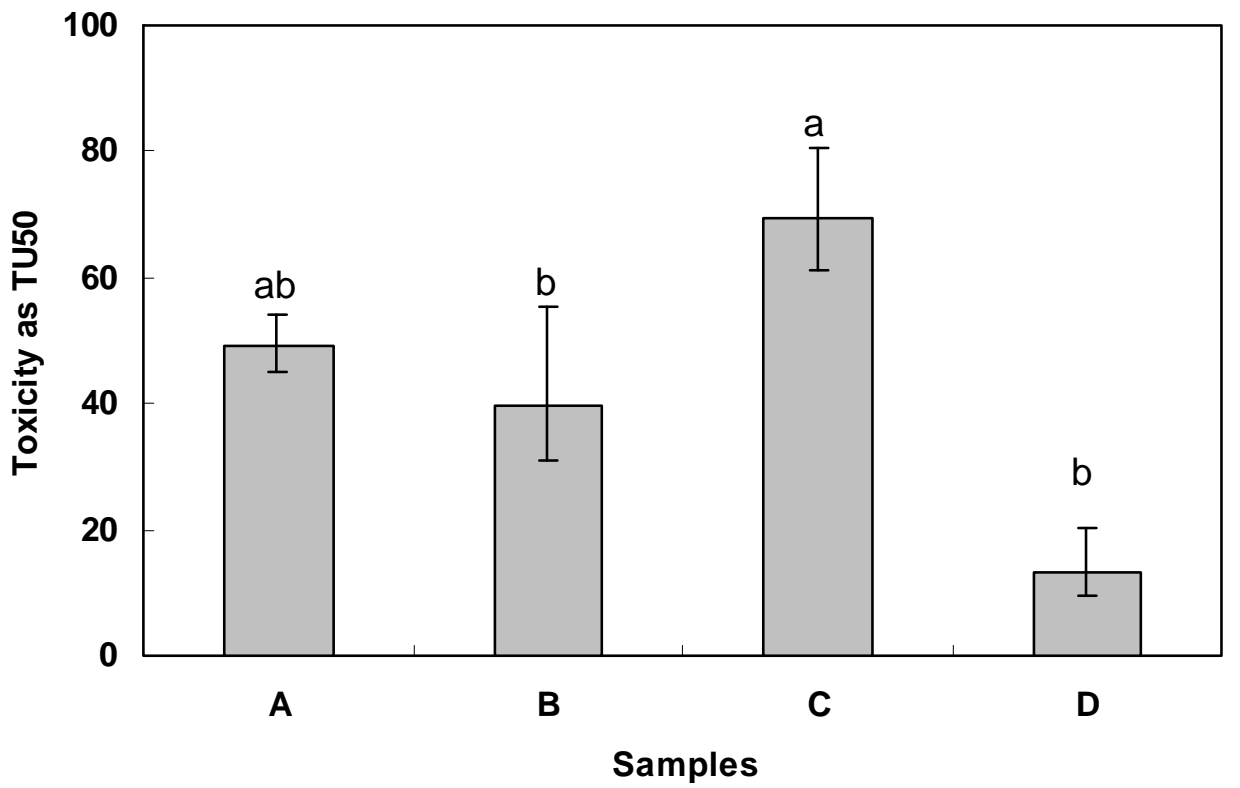


Fig.3. Inhibition fluorescence percentage in Stabilized Aqueous Photosynthetic Systems (SAPS) after three different exposure times (30 min, $2 \mathrm{~h}$ and $24 \mathrm{~h}$ ) at $250 \mathrm{~g}$ sediment $\mathrm{L}^{-1}$. Means $(n=3) \pm 1$ SD: with different letters differed significantly (Fisher's test at $p<0.001$ ) after significant global ANOVA $(p<0.0001)$.

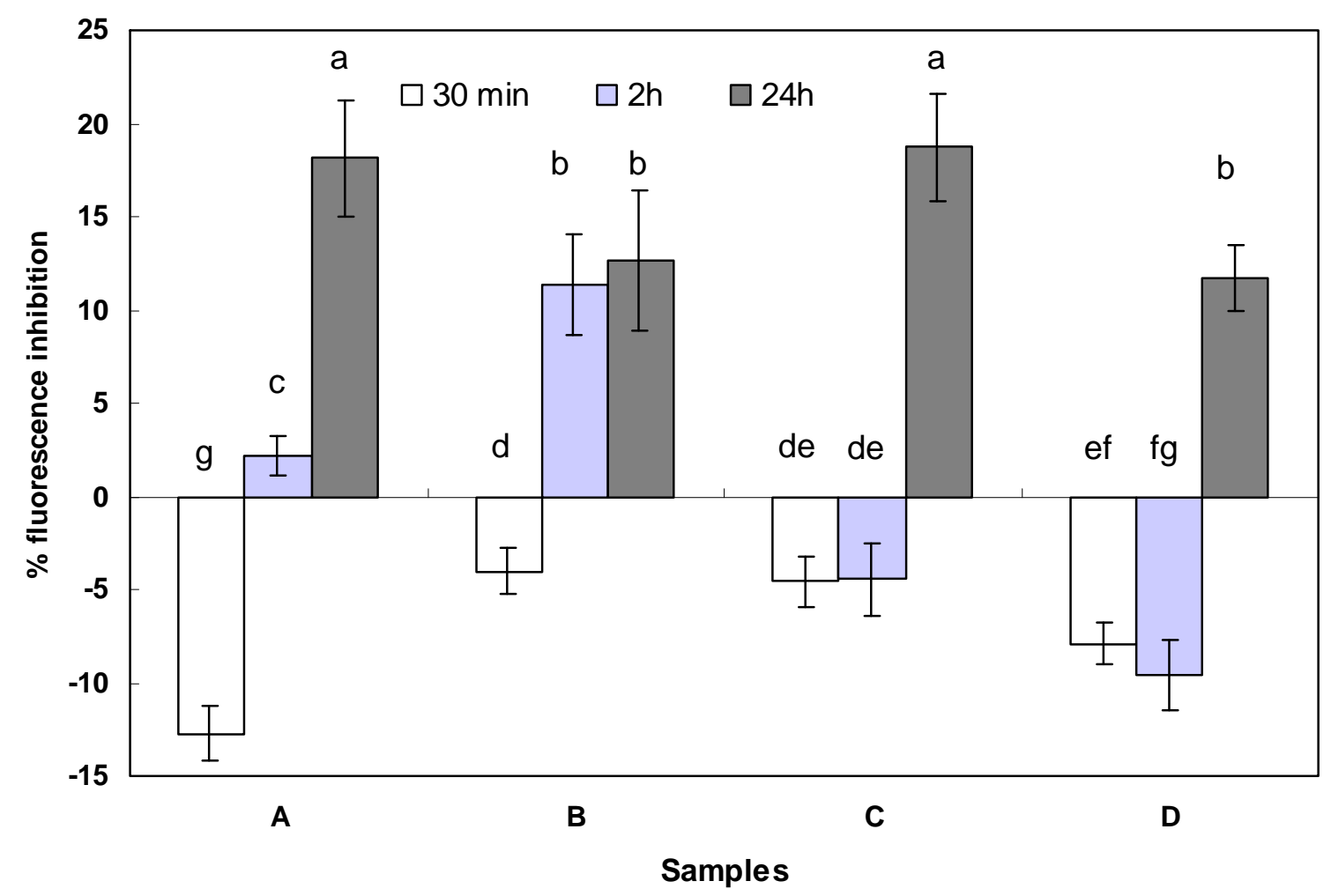


Fig.4. Sediment toxicity determined in elutriates $\left(100 \mathrm{~g}\right.$ sediment $\left.\mathrm{L}^{-1}\right)$ as inhibition of the dicotyl flax (Linum usitatissimum) seeds germination $(24 \mathrm{~h}$ ), reduction of root biomass and root length after $48 \mathrm{~h}$ and $72 \mathrm{~h}$. Means $(\mathrm{n}=3) \pm 1 \mathrm{SD}$ : different letters differed significantly (Fisher's test at $p<0.001)$ after significant global ANOVA $(p<0.0001)$.

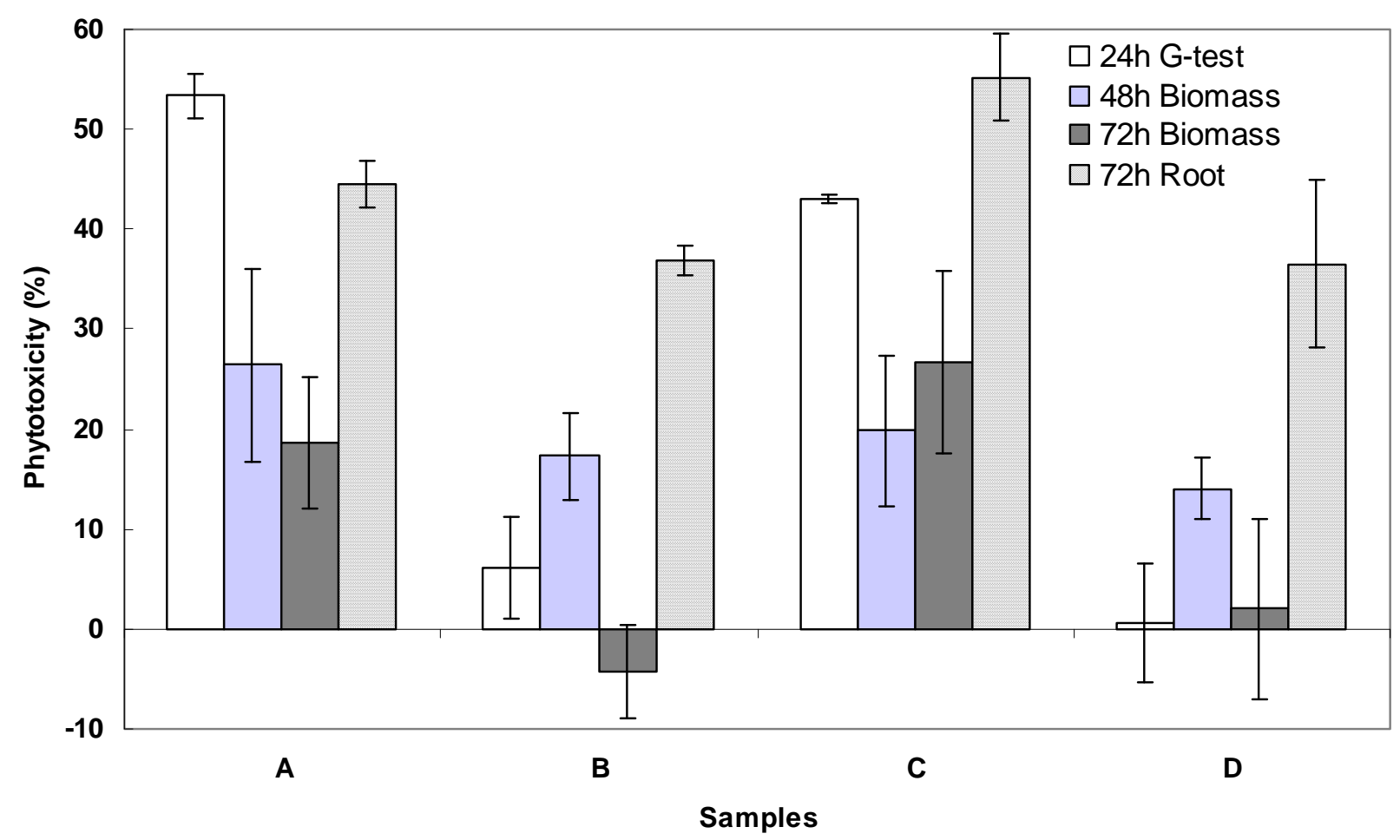

Fig.5. Phytotoxkit results : root growth inhibition percentages in the monocotyl sorgho Sorghum saccharatum and the dicotyl garden cress Lepidium sativum exposed to elutriates (100 g sediment $\mathrm{L}^{-1}$ ) from sediment samples during $3 \mathrm{~d}$. Means $(n=3) \pm 1$ SD: different letters differed significantly (Fisher's test at $p<0.001)$ after significant global ANOVA $(p<$ 0.0001).

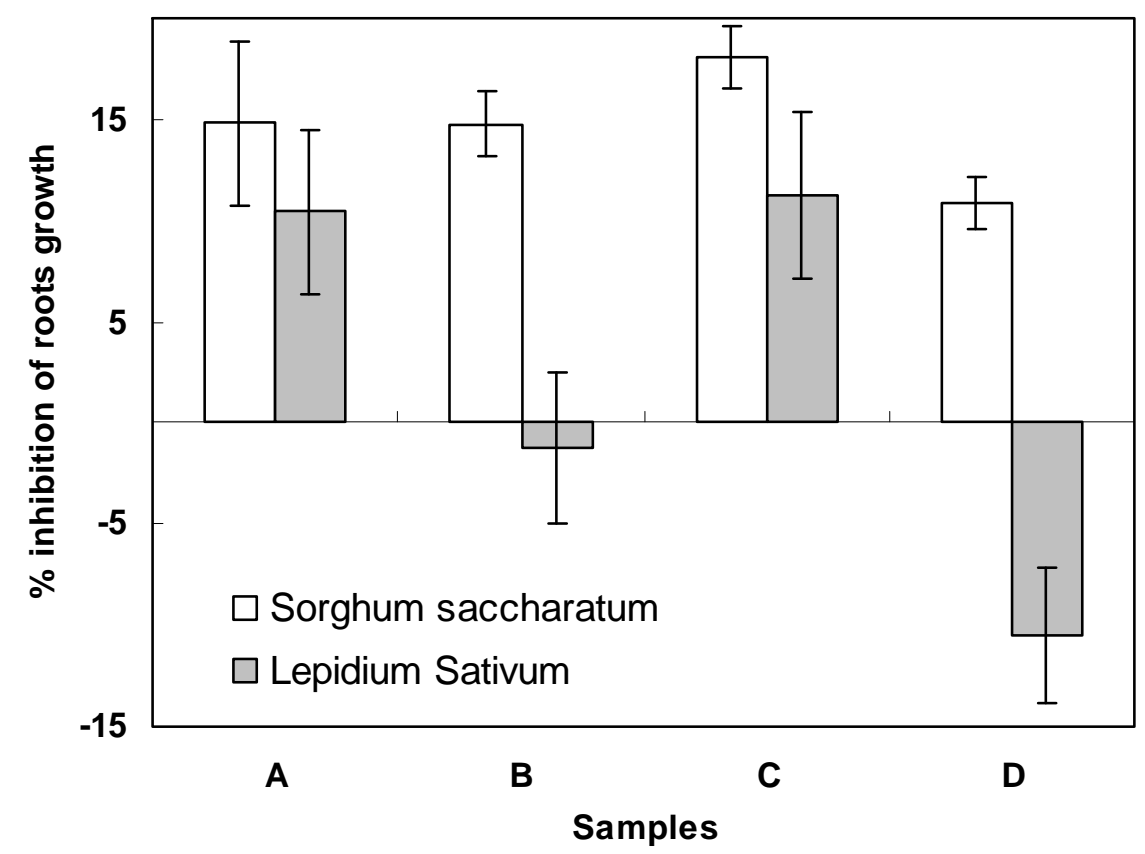


Fig.6. PCA analysis using chemical data and bioassays responses.

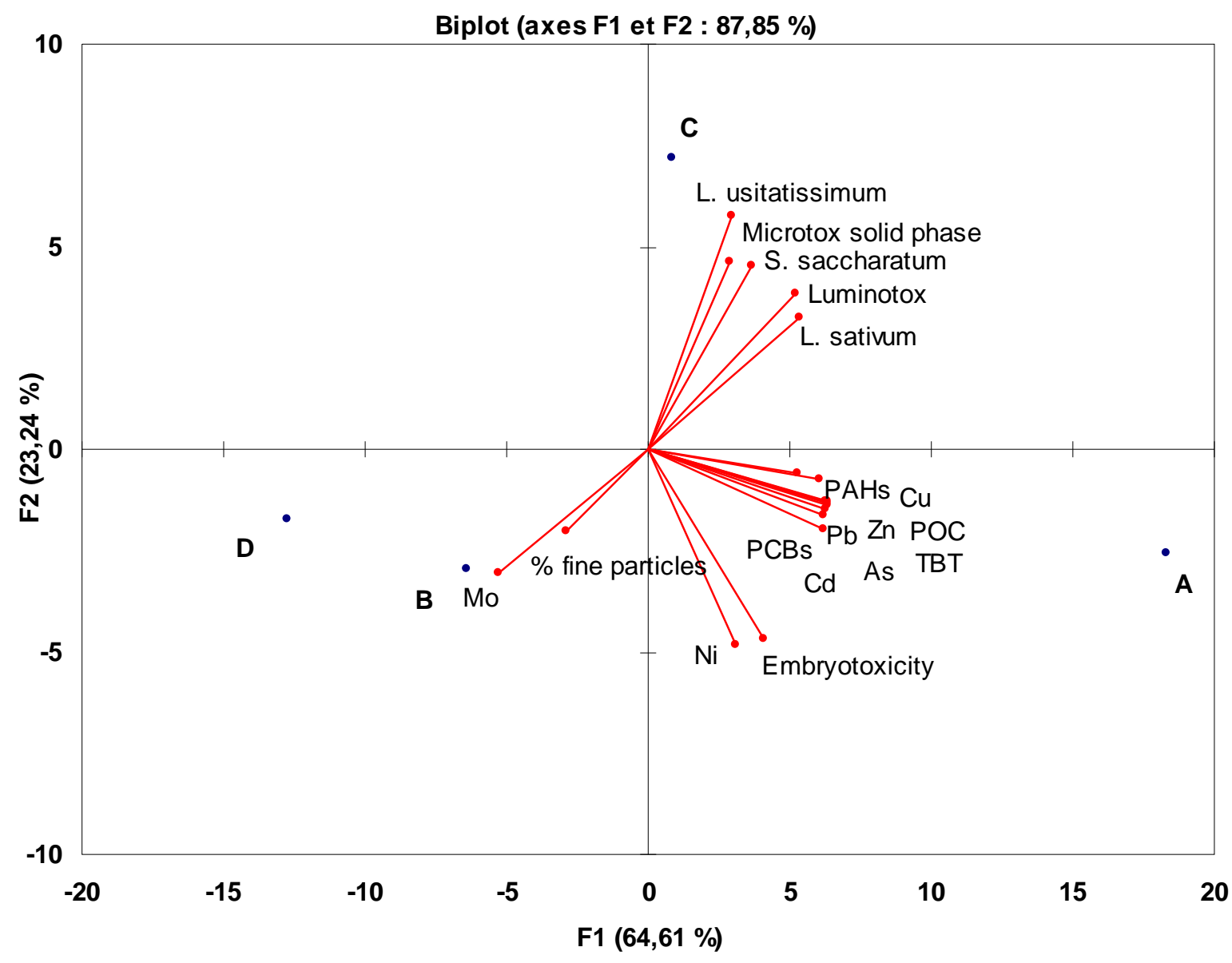


Table 1. Physico-chemical composition of sediments on a dry weight basis. N1 and N2 (metals and PCBs) levels in the whole sediment from Alzieu and Quiniou (2001). For PAH (sum of PAHs) and TBT no regulatory levels are defined and provisory values have been proposed (Alzieu and Quiniou, 2001).

\begin{tabular}{|c|c|c|c|c|c|c|c|}
\hline Parameters & Units & $A$ & B & $\mathrm{C}$ & $\mathrm{D}$ & Legal level N1 & Legal level N2 \\
\hline Water content & $\%$ & 15.6 & 27.21 & 25.4 & 21.30 & - & - \\
\hline Fine particle $(<63 \mu \mathrm{m})$ & $\%$ & 21.8 & 64.7 & 28.4 & 28.2 & - & - \\
\hline POC & $\mathrm{g} \mathrm{kg}^{-1}$ d.m. & 69 & 45 & 43 & 36 & - & - \\
\hline As & $\mathrm{mg} \mathrm{kg}^{-1}$ d.m. & 129 & 43 & 35 & 14 & 25 & 50 \\
\hline $\mathrm{Cd}$ & $\mathrm{mg} \mathrm{kg}^{-1}$ d.m. & 4.6 & 1.1 & 1.5 & 0.8 & 1.2 & 2.4 \\
\hline $\mathrm{Cu}$ & $\mathrm{mg} \mathrm{kg}^{-1} \mathrm{~d} . \mathrm{m}$. & 902 & 241 & 362 & 174 & 45 & 90 \\
\hline Mo & $\mathrm{mg} \mathrm{kg}^{-1} \mathrm{~d} . \mathrm{m}$ & 10 & 18 & 11 & 16 & - & - \\
\hline $\mathrm{Ni}$ & $\mathrm{mg} \mathrm{kg}^{-1} \mathrm{~d} . \mathrm{m}$ & 28 & 30 & 16 & 19 & 37 & 74 \\
\hline $\mathrm{Pb}$ & $\mathrm{mg} \mathrm{kg}^{-1} \mathrm{~d} . \mathrm{m}$ & 896 & 271 & 400 & 116 & 100 & 200 \\
\hline $\mathrm{Se}$ & $\mathrm{mg} \mathrm{kg}^{-1}$ d.m. & $<2$ & $<2$ & $<2$ & $<2$ & - & - \\
\hline $\mathrm{Zn}$ & $\mathrm{mg} \mathrm{kg}^{-1} \mathrm{~d} . \mathrm{m}$. & 1,932 & 611 & 865 & 242 & 276 & 552 \\
\hline MBT & $\mu \mathrm{g} \mathrm{Sn} \mathrm{kg}^{-1}$ & 2,126 & 166 & 452 & 382 & - & - \\
\hline DBT & $\mu \mathrm{g} \mathrm{Sn} \mathrm{kg}{ }^{-1}$ & 1,028 & 165 & 935 & 562 & - & - \\
\hline TBT & $\mu \mathrm{g} \mathrm{Sn} \mathrm{kg}^{-1}$ & 6,398 & 323 & 3,001 & 941 & 100 & 400 \\
\hline PAHs & $\mathrm{mg} \mathrm{kg}^{-1} \mathrm{~d} . \mathrm{m}$ & 31.34 & 7.36 & 9.33 & 2.80 & 1.5 & 15 \\
\hline PCBs & $\mathrm{mg} \mathrm{kg}^{-1} \mathrm{~d} . \mathrm{m}$ & 0.73 & 0.23 & 0.41 & 0.21 & 0.5 & 1 \\
\hline$Q_{P E C m}$ & - & 14.7 & 2.5 & 6.1 & 1.2 & - & - \\
\hline
\end{tabular}

Total PAHs $=\sum$ (Fluoranthene, Benzo(b)fluororanthene, Benzo(k)fluoranthene, Benzo(a)pyrene, Benzo(ghi)perylene and Indeno(1,2,3-cd)pyrene).

PCBs $=$ = congeners 28, 52, 101, 118, 138, 153, 180.

$Q_{\mathrm{PECm}}$ : Risk quotient (Perrodin et al., 2006). 